NOTES ON THE NEW-TESTAMENT CANON OF EUSEBIUS. 


\title{
NOTES ON THE NEW-TESTAMENT CANON OF EUSEBIUS.
}

\author{
By Rev. ARTHUR CUSHMAN McGIFFERT, PH.D.
}

Instructor in Church History, Lane Theological Seminary, Cincinnati, O.

I do not propose to enter into a discussion of the general subject of Eusebius' New-Testament canon; I desire to do little more than suggest an interpretation of the classical passage in $H$. E., III., 25.

This is the only place in which Eusebius attempts to treat the canon systematically, and in it he is speaking purely as an historian, not as a critic. $\mathrm{He}$ is endeavoring to give an accurate statement of the general opinion of the orthodox church of his day in regard to the number and names of its sacred books. He does not, in this passage, apply to the various works any criterion of canonicity further than their acceptance as canonical by the orthodox church. He simply records the state of the canon; he does not endeavor to form a canon. He has nothing to do, therefore, with the nature and origin of the books which the church accepts. The church whose judgment he takes is, in the main, the church of the Orient, and in that church at this time all the works which we now call canonical (and only those) were already commonly accepted, or were becoming more and more widely accepted as such. From the standpoint, then, of canonicity, Eusebius divided the works which he mentions in this chapter into two classes: the canonical (including the homologoumena and the antilegomena), and the uncanonical

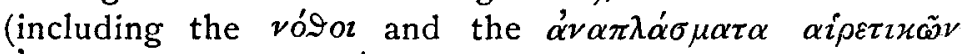
$\alpha v \delta \rho \tilde{v} v)$. But the róqou he connects much more closely. with the homologoumena and antilegomena than with the heretical works, which are, in fact, separated from all the 
rest and placed in a class by themselves. What, then, is the relation of the homologoumena, antilegomena, and vógor to each other, as Eusebius classifies them? The crucial point

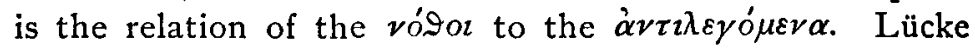
identified the two, but such identification is impossible. The passages which he cited to confirm his view prove only that the two terms are commonly employed by Eusebius in a loose sense, and establish nothing as to his technical use of them in his systematic treatment of the subject. Various views have been taken since Lücke's time upon the relation of these terms to each other, but, to me at least, none of them seem satisfactory, and I have been led to adopt the following simple explanation. The antilegomena were works which, in Eusebius' day, were, as he believed, commonly accepted by the Eastern church as canonical, but which, nevertheless, as he well knew, had not always been thus accepted, and indeed were not even then universally accepted as such. The tendency, however, was distinctly in the direction of their ever wider acceptance. On the other hand, the vó $90 z$ were works which, although they had been used by the Fathers and were quoted as $\gamma \rho \alpha \varphi \dot{\eta}$ by some of them, were, at this time, not acknowledged as canonical. Although perhaps not universally rejected from the canon, yet they were commonly so rejected, and the tendency was distinctly in the direction of their ever wider rejection. Whatever their merit, and whatever their antiquity and their claims to authenticity, Eusebius could not place them among the canonical books. The term vó 90 , then, in this passage must not be taken, as it so commonly is, to mean spurious, or unauthentic, but to mean uncanonical. It is in this sense as against the canonical homologoumena and antilegomena that Eusebius, as I believe, uses it here, and his use of it in this sense is perfectly legitimate. In using it he passes no judgment upon the authenticity of the works referred to ; that, in the present case, is not his concern. As an historian he observed tendencies, and judged accordingly. He saw that the authority of the antilegomena was on the increase, that of the vósor on the decrease, and already he could draw a 
distinction sharply between them, as Clement of Alexandria could not do a century before. The distinction drawn has no relation to the authenticity or original authority of the works of the two classes, but only to their canonicity or uncanonicity at the time Eusebius wrote.

This interpretation will help us to understand the peculiar way in which Eusebius treats the Apocalypse, and thus his treatment of it becomes an argument in favor of the interpretation. He puts it, first, among the homologoumena with

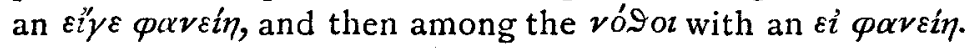
No one, so far as I know, has explained why it should be put among the $\nu$ ó $\$ o u$ as an alternative to the homologoumena, instead of among the antilegomena, which, on the common interpretation of the relation of the classes, might be naturally expected. If the view presented is correct, the reason is clear. The antilegomena were those works which had been disputed, but were becoming more and more widely accepted as canonical. The Apocalypse could not, under any circumstances, fall into this class, for the doubts raised against it in the orthodox church were of recent date. It occupied, in fact, a peculiar position, for there was no other work which, while accepted as canonical, was doubted in the present more than in the past. Eusebius then must either put it into a special class or put it conditionally into two different classes, as he does. If the doubts should become so widespread as to destroy its canonicity, it would fall naturally into the ró 9 , for then it would hold the same position as the other works of that class. As an historian, Eusebius sees the tendency and undoubtedly has the idea that the Apocalypse may eventually, like the other Christian works of the same class (the Shepherd, the Apocalypse of Peter, etc.), become one of the rógor, one of the works which, formerly accepted, is at length commonly denied to be canonical ; and so, as an historian, he presents the alternative. The Apocalypse was the only work in regard to which any doubt could exist.

Eusebius' failure to mention explicitly in this passage the Epistle to the Hebrews, has caused considerable misunder- 


\section{Notes on the Neru-Testament Canon of Eusebius.}

standing. The explanation, if the view presented be adopted, is simple. Eusebius included it, I believe, among the epistles of Paul, and did not especially mention it, simply because there was no dispute about its canonicity. Its Pauline authorship had been widely disputed, as Eusebius informs us elsewhere, and various theories had been proposed to account for it ; but its canonicity had not been doubted in the orthodox church, and therefore doubts as to the authorship of it did not in the least endanger its place among the homologoumena, as used here in a technical sense; and since Eusebius was simply stating the works of each class, not discussing the nature and origin of those works, he could, in perfect fairness, include it in Paul's epistles (where he himself believed it belonged) without entering upon any discussion of it.

Another noticeable omission is that of the Epistle of Clement to the Corinthians. All efforts to find a satisfactory reason for this are fruitless. It should have been placed among the vógor with the Epistle of Barnabas, etc., as Eusebius' treatment of it in other passages shows. It must be assumed that the omission of it was nothing more nor less than an oversight.

Eusebius, then, classifies the works mentioned in $H$. $E$. III., 25 , upon two principles: first, in relation to canonicity, into the canonical and the uncanonical ; and secondly, in relation to character, into the orthodox (homologoumena, antilegomena, which are canonical, and $\nu o ́ \$ 0 z$ which are uncanonical), and heterodox (which are not, and never have been, canonical, never have been accepted as of use or authority). The homologoumena and antilegomena, then, are both canonical

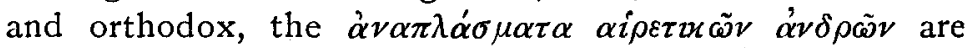
neither canonical nor orthodox, while the vó $90 z$ occupy a peculiar position, being orthodox but not canonical. The last-named are much more closely related to the canonical than to the heterodox works, because when the canon was a less concrete and exact thing than it had at length become, they were associated with the other orthodox works as, like them, useful for edification and instruction. With the heretical works they had never been associated, and possessed 
Notes on the Nerw-Testament Canon of Eusebius. 255

in common with them only the negative characteristic of non-canonicity. Eusebius naturally connects them closely with the former, and severs them completely from the latter.

The only reason for mentioning the latter at all was the fact that they bore the names of apostles, and thus might be supposed, as they often had been-by Christians, as well as by unbelievers,- to be sacred books like the rest. The statement of the canon gives Eusebius an opportunity to warn his readers against them. 